\title{
PENGARUH PERPUTARAN KAS, PERPUTARAN PIUTANG, DAN PERPUTARAN PERSEDIAAN TERHADAP PROFITABILITAS PADA PT DELTA DJAKARTA TBK PRIODE 2014 - 2018
}

\author{
Fuad Makarim' \\ fuadmakarim96@gmail.com \\ Fakultas Ekonomi Dan Bisnis Universitas Islam Syekh Yusuf Tangerang \\ Rosyid, SE., MM² \\ Fakultas Ekonomi Dan Bisnis Universitas Islam Syekh Yusuf Tangerang \\ Umi Kulsum, SE., MM ${ }^{3}$ \\ Fakultas Ekonomi Dan Bisnis Universitas Islam Syekh Yusuf Tangerang
}

\begin{abstract}
This study aims to find empirical evidence about factors that influence Cash Turnover, Receivables Turnover, Inventory Turnover on Profitability. The factor tested in this study is ReturnOnAssets. The sample in this study used I beverage subsector manufacturing company in the 20I4-20I8 period. Samples were taken using the Quantitative method. These factors are then tested using descriptive statistical test methods, multiple linear regression, multiple correlation, determination coefficient, $t$ test, $f$ test, SPSS 25.00.The results in this study indicate that based on a partial test the Cash Turnover variable is accepted and not significant to Profitability, and the Receivable Turnover variable is rejected and not significant to profitability, while the Inventory Turnover variable has a significant positive effect on Profitability. Based on the Simultaneous Test variable Cash Turnover, Receivable Turnover, Inventory Turnover have a rejected and significant influence on profitability.
\end{abstract}

Keywords: Return On Assets, kas, piutang

\section{A. PEndahuluan}

Tujuan managemen keuangan adalah untuk memaksimalkan nilai prusahaan. Dengan demikian apabila suatu saat prusahaan dijual, maka harganya dapat ditetapkan setinggi mungkin. Seorang manager juga harus mampu menekan arus predaran uang agar terhindar dari tindakan yang tidak diinginkan.

Profitabilitas mempunyai peran penting dalam perusahaan sebagai cerminan masa depan apakah perusahaan mempunyai prospek yang baik di masa mendatang. Bagi perusahaan masalah profitabilitas sangatlah penting. Bagi pemimpin perusahaan profitabilitas digunakan untuk melihat seberapa besar kemajuana tau berhasil tidak perusahaan yang dipimpinnya. Sedangkan bagi karyawan perusahaan apabila semakin tinggi keuntungan yang diperoleh perusahaan tempat kerjanya, maka ada kesempatan baginya untuk dapat kenaikan gaji.

Ada beberapa alatukur yang dapat digunakan dalam mengukur tingkat profitabilitas, yaitu: Net Profit Margin (NPM), Return Onlnvesment (ROI), Return On Asset (ROA), dan Return On Equity (ROE). Untuk mengetahui seberapa besar keuntungan (profitabilitas) yang akan dihasilkan oleh perusahaan, dalam penelitian ini profitabilitas diukur dengan menggunakan Return On Asset (ROA). Return On Asset (ROA) yang merupakan kemampuan perusahaan secara keseluruhan di dalam menghasilkan keuntungan dengan jumlah keseluruhan aktiva yang tersedia di dalam perusahaan.

Adapun komponen modal kerja meliputi kas, piutang, dan persediaan. Untuk menentukan kebutuhan modal kerja yang akan digunakan perusahaan dalam kegiatan operasionalnya, maka dapat dilihat dari perputaran masing-masing modal kerja itu sendiri, seperti perputaran kas, perputaran persediaan, dan perputaran piutang. Kas merupakan bentuk aktiva yang paling liquid di dalam neraca, karena kas merupakan aktiva lancer yang sewaktu-waktu dapat digunakan dalam kegiatan operasional perusahaan. kas sangant penting bagi perusahaan karena kas adalah unsur modal kerja dan bagian dari investasi.

Komponen kedua adalah piutang. Dalam dunia usaha dengan persaingan yang sangatketat salah satucara yang dapat dilakukan untuk mempertahankan pelanggan adalah dengan melakukan penjualan kredit. Penjualan kredit tersebut yang akan menimbulkan piutang, yang merupakan kegiatan yang terjadi karena adanya penjualan secara kredit barang dagang atau jasa. 
Komponen ketiga adalah persediaan. Proses penjualan tidak lepas dari pengaruh persediaan yang dimiliki oleh perusahaan. Persediaan merupakan pos aktiva lancar perusahaan yang nilainya cukup besar sehingga pos persediaan memiliki peran penting bagi perusahaan. Persediaan merupakan unsur yang aktif dalam kegiatan operasional perusahaan, karena jumlah persediaan dalam perusahaan selalu berubah karena adanya pengurangan untuk proses produksi yang akan dijual kepada konsumen.

\section{Pengertian Profitbilitas}

Profitabilitas adalah kemampuan suatu prusahaan dalam menghasilkan laba selama priode tertentu pada tingkat penjualan, asset dan modal saham tertentu. Profitabilitas suatu prusahaan dapat dinilai melalui berbagai cara tergantung pada laba dan aktiva atau modal yang akan diperbandingkan satu dengan lainnya.

Profitabilitas merupakan rasio untuk menilai kemampuan prusahaan dalam mencari keuntungan, rasio ini juga memberikan ukuran tingkat efektivitas managemen suatu prusahaan. Hal ini tunjukkan oleh laba yang dihasilkan dari penjualan dan pendapatan investasi. Menurut V.WiratnaSujarweni (2016:I I4).

\section{Pengertian Kas}

Perputaran kas merupakan kemampuan kas untuk menghasilkan pendapatan sehingga dapat dilihat beberapa kali uang kas berputar dalam satu priode tertentu.

Secara khusus uang kas kita katakan sebagai uang tunai yang dimiliki oleh suatu prusahaan dan tercatat dalam neraca pada posisi aktiva lancar. Kas secara umum juga diartikan sebagai uang yang disimpan dibank, yang dapat diuagkan setiap saat. Didalam neraca kas ditempat kan diposisi nomor satu dalam aktiva lancar, karna merupakan aktiva yang paling likuid diantara aktiva yang dimiliki prusahaan (Kasmir2016 : I88).

\section{Pengertian Piutang}

Perputaran piutang merupakan rasio yang digunakan untuk mengukur berapa lama penagihan piutang selama satu periode. Atau beberapa kali dana yang ditanam dalam piutang ini berputar dalam satu periode.

"Piutang adalah klaim prusahaan atas uang, barang, atau jasa kepada pihak lain akibat transaksi dimasalalu (Rudianto2012 : 210)"

\section{Pengertian Persediaan}

Perputaran persediaan merupakaan cara untuk mengetahui berapa kali pesediaan prusahaan terjual atau tergantikan dalam satu periode tertentu. Perputaran persediaan mengukur kecepatan perusahaan menjual persediaanya dan dibandingkan dengan perusahaan lain yang sejenis.

"Persedaiaan adalah sejumlah barang jadi, bahan baku, dan barang dalam proses yang dimiliki prusahaan dengan tujuan untuk dijual atau proses lebih lanjut (V. Wiratna Sujarweni 2016 : 196)".

\section{B. METODE PENELITIAN}

Metode kuantitatif dinamakan metode tradisional karna metode ini sudah cukup lama digunakan sehingga sudah mentradisi sebagai metode untuk penelitian.

Metode ini juga disebut metode kuantitatif karena penelitian berupa angka-angka dan analisis menggunakan statistik.

Dalam pengelolaan data pada statistic dengan menggunakan SPSS 25, maka perlu dilakukan pengelompokan data sebagai tahap awal.

\section{Populasi}

Dalam Sugiyono (2017: 80) definisi populasi: "populasi adalah wilayah generasi yang terdiri atas; obyek/subyek yang mempuyai kualitas dan karakteristik tertentu yang ditetapkan oleh peneliti untuk dipelajari dan kemudian ditarik kesimpulannya".

Populasi dalam penelitian ini adalah satu prusahaan yang terdapat di Bursa Efek Indonesia yaitu PT. Delta Djakarta Tbkpriode 20I4-20I8.

\section{Sampel}

Menurut Sugiono (20I7: 8I) sampel adalah sebagai berikut: "sampel adalah bagian dari jumlah dan karakteristik yang dimiliki oleh populasi tersebut. Bila populasi besar, dan peneliti tidak mungkin mempelajari semua yang ada pada populasi, misalnya karena keterbatasan dana, tenaga dan waktu, maka penelitian dapat menggunakan sampel yang diambil dari populasi itu". 


\section{Uji Asumsi Klasik}

\section{I.Uji Multikolineritas}

Diperlukan untuk mengetahui ada tidaknya variabel indevenden yang memiliki kemiripan dengan variabel indevenden lain dalam satu model.

\section{Uji Normalitas}

Merupakan suatu jenis uji statistic untuk menentukan apakah suatu populasi berdistribusi normal atau tidak.

\section{Uji Heteroskesdastisitas}

Bertujuan untuk menguji terjadinya perbedaan variance residual suatu periode pengamatan kepriode pengamatan yang lain.

\section{Analisis Regresi Linier Berganda}

Regresi bertujuan untuk menguji hubungan pengaruh antara satu variabel terhadap variabel lainnya. Regresi yang dimiliki satu variabel dependen dan lebih dari satu variabel indevenden disebut regresi berganda.

\section{Uji Determinasi Dengan F-Tes Uji Signifikansi}

Koefisien determinasi (R2) bertujuan untuk mengetahui seberapa besar variabel indevenden dapat menjelaskan variabel dependen. Koefisien determinasi berganda terletak di mode Isummary dan tertulis $\mathrm{R}$ square.

\section{Uji Parsial dengan T-Tes Signifikansi}

T-tes bertujuan untuk mengetahui besarnya pengaruh masing-masing variabel; indevenden secara individual (parsial) terhadap variabel dependen.

\section{HASIL DAN PEMBAHASAN \\ Uji Asumsi Klasik}

\section{Uji Normalitas}

\begin{tabular}{|c|c|c|}
\hline \multicolumn{3}{|c|}{ One-Sample Kolmogorov-Smirnov Test } \\
\hline & & $\begin{array}{c}\text { Unstandard } \\
\text { ized } \\
\text { Residual }\end{array}$ \\
\hline \multicolumn{2}{|l|}{$\mathbf{N}$} & 5 \\
\hline \multirow[t]{5}{*}{ Normal Parameters ${ }^{\mathrm{a}, \mathrm{b}}$} & & .0000000 \\
\hline & Mean & \\
\hline & & \\
\hline & & 01926635 \\
\hline & Deviation & \\
\hline \multirow{3}{*}{$\begin{array}{l}\text { Most Extreme } \\
\text { Differences }\end{array}$} & Absolute & .267 \\
\hline & Positive & .267 \\
\hline & Negative & -.267 \\
\hline \multicolumn{2}{|l|}{ Test Statistic } & .267 \\
\hline Asymp. Sig. (2-tailed) & & $.200^{c, d}$ \\
\hline \multicolumn{3}{|c|}{ a. Test distribution is Normal. } \\
\hline \multicolumn{3}{|c|}{ b. Calculated from data. } \\
\hline \multicolumn{3}{|c|}{ c. Lilliefors Significance Correction. } \\
\hline
\end{tabular}

Berdasarkan tabel dari hasil uji Normalitas penelitian dapat diketahui bahwa semua variabel penelitian mempunyai nilai signifikan lebih besar dari $0.05(0,200>0.05)$, sehingga dapat disimpulkan bahwa semua variabel penelitian berdistribusi normal. Tabel tersebut menunjukan bahwa nilai statistic untuk variabel unstandardized residual adalah sebesar 0.267. oleh karena itu variabel penelitian mempunyai profitabilitas 0.200 yang lebih besar dari 0.05 maka semua vaiabel dalam penilitian ini berdistribusi normal. 


\section{Uji Multikolineritas}

\begin{tabular}{|l|l|r|r|}
\hline \multicolumn{3}{|c|}{ Coefficients $^{\mid 2}$} \\
\hline \multicolumn{2}{|l|}{ Model } & \multicolumn{1}{|c|}{ Collinearity Statistics } \\
\cline { 3 - 4 } \multicolumn{2}{|l|}{} & Tolerance & \multicolumn{1}{c|}{ VIF } \\
\hline 1 & KAS & .437 & 2.287 \\
\cline { 2 - 4 } & PIUTANG & .328 & 3.052 \\
\cline { 2 - 4 } & PERSEDI & .432 & 2.316 \\
& AAN & & \\
\hline \multicolumn{2}{|l|}{ a. Dependent Variable: ROA } \\
\hline
\end{tabular}

Berdasarkan tabel di atas, menunjukkan bahwa data pada variabel bebas tidak mengandung adanya gejala korelasi yang kuat antara sesama variabel bebas, karena semua nilai VIF yang dihitung lebih kecil dari 10 dan nilai tolerance diatas 0,1 , maka dapat disimpulkan tidak terdapat multikolinieritas diantara variabel bebas.

\section{Uji Heteroskedastisitas}

\begin{tabular}{|c|c|c|c|c|c|c|}
\hline \multirow{2}{*}{\multicolumn{2}{|c|}{ Model }} & \multicolumn{2}{|c|}{$\begin{array}{l}\text { Unstandardized } \\
\text { Coefficients }\end{array}$} & $\begin{array}{l}\text { Standardized } \\
\text { Coefficients }\end{array}$ & \multirow[t]{2}{*}{$\mathrm{T}$} & \multirow[t]{2}{*}{ Sig. } \\
\hline & & B & Std. Error & Beta & & \\
\hline \multirow[t]{4}{*}{1} & (Constant) & .254 & .127 & & 2.001 & .295 \\
\hline & KAS & .000 & .000 & -1.059 & -4.608 & .136 \\
\hline & PIUTANG & -.002 & .004 & -.130 & -.488 & .711 \\
\hline & PERSEDIAAN & .034 & .006 & 1.244 & 5.379 & .117 \\
\hline
\end{tabular}

a.DependentVariabel: abs_res_1

Berdasarkan tabel diatas menunjukkan bahwa nilai signifikansi variabel Kas sebesar 0,136, nilai signifikansi variabel Piutang sebesar 0,7II dan nilai signifikansi variabel profitabilitas (ROA) sebesar 0,II7, maka hasil nilai signifikansi variabel Perputaran Kas, Perputaran Piutang dan Perputaran Persediaan menunjukkan lebih besar dari 0,05 maka kesimpulannya tidak terjadi gejala Heteroskedasitas di dalam model regresi.

\section{Uji Regresi Berganda}

\begin{tabular}{|c|c|c|c|c|c|c|}
\hline \multicolumn{7}{|c|}{ Coefficients ${ }^{a}$} \\
\hline & \multirow{2}{*}{ Model } & \multicolumn{2}{|c|}{$\begin{array}{l}\text { Unstandardized } \\
\text { Coefficients }\end{array}$} & \multirow{2}{*}{$\begin{array}{c}\begin{array}{c}\text { Standardized } \\
\text { Coefficients }\end{array} \\
\text { Beta }\end{array}$} & \multirow[t]{2}{*}{$\mathrm{t}$} & \multirow[t]{2}{*}{ Sig. } \\
\hline & & $\mathrm{B}$ & $\begin{array}{c}\text { Std. } \\
\text { Error }\end{array}$ & & & \\
\hline \multirow[t]{4}{*}{1} & (Constant) & .254 & .127 & & 2.001 & .295 \\
\hline & KAS & .000 & .000 & -1.059 & -4.608 & .136 \\
\hline & PIUTANG & -.002 & .004 & -.130 & -.488 & .711 \\
\hline & PERSEDIAAN & .034 & .006 & 1.244 & 5.379 & .117 \\
\hline \multicolumn{7}{|c|}{ a. Dependent Variable: ROA } \\
\hline
\end{tabular}

Berdasarkan output di atas, diperoleh nilai a sebesar 0,254 nilai b| sebesar 0,000 nilai b2 sebesar $-0,002$ dan nilai b3 sebesar 0,034. Dengan demikian maka dapat dibentuk persamaan regresi linier berganda sebagai berikut :

$Y=0,254-0,000 X 1+-0,002 \times 2+0,034 X 3$

Dimana nilai a dan $b$ dalam persamaan di atas dapat diinterpretasikan sebagai berikut :

$a=0,254 \quad$ artinya : jika variabel perputaran kas $(X 1)$, perputaran piutang $\left(X_{2}\right)$ dan perputaran persediaan $\left(\mathrm{X}_{3}\right)$ bernilai 0 maka profitabilitas pada Perusahaan Delta Djakarta Tbk akan meningkat sebesar 0,254 .

bl $=0,000$ artinya : jika perputaran kas $(X \mathrm{I})$ meningkat sebesar satu, maka profitabilitas pada Perusahaan Delta Djakarta Tbk akan meningkat sebesar 0,000.

b2 $=-0,002$ artinya : jika perputaran piutang $(X 2)$ meningkat sebesar satu, maka profitabilitas pada Perusahaan Delta Djakarta Tbk akan meningkat sebesar -0,002. 
b3 $=0,034 \quad$ artinya : jika perputaran persediaan $\left(X_{3}\right)$ meningkat sebesar satu, maka profitabilitas pada Perusahaan Delta Djakarta Tbk akan meningkat sebesar 0,034.

\section{Uji T Pengujian Hipotesis Secara Parsial (Uji t)}

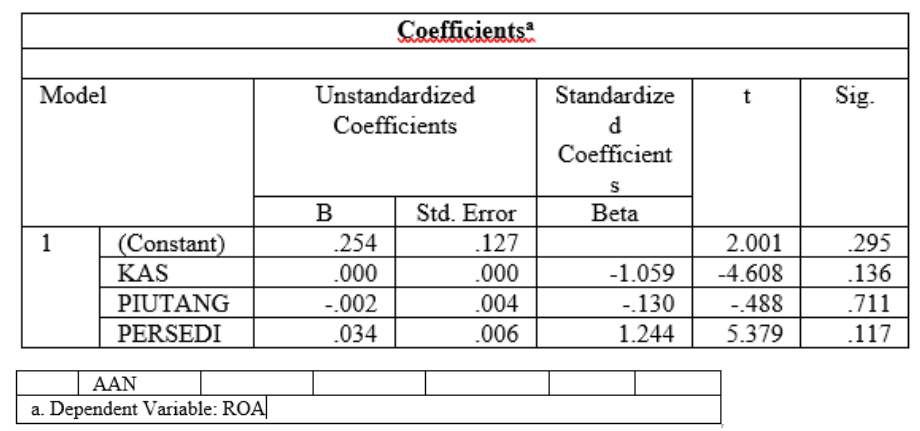

a. Pengujian Hipotesis Variabel XI (Perputaran Kas)

Dari tabel di atas diperoleh nilai thitung untuk perputaran kas $\left(X_{1}\right)$ sebesar $-4,608$ dan tabel sebesar $-1,9705$. Dikarenakan nilai thitung lebih besar dari ttabel $(-4,608>-1,9705)$ dengan nilai signifikansi 0,136>0,05 maka H0 diterima, artinya modal kerja dalam perputaran kas (XI) tidak berpengaruh secara signifikan terhadap profitabilitas $(\mathrm{Y})$ pada Perusahaan Delta Djakarta Tbk.

b. Pengujian Hipotesis Variabel X2 (Perputaran Piutang)

Dari tabel di atas diperoleh nilai thitung untuk perputaran piutang $\left(X_{2}\right)$ sebesar $-0,488$ dan ttabel I,9705. Dikarenakan nilai thitung $<$ ttabel $(-0,488<I, 9705)$ dengan nilai signifikansi 0,7I I $<0,05$ maka $\mathrm{H} 0$ ditolak, artinya Modal kerja dalam perputaran piutang (X2) tidak berpengaruh secara signifikan terhadap profitabilitas (Y) pada Perusahaan Delta Djakarta Tbk.

c. Pengujian Hipotesis Variabel $\mathrm{X} 3$ (Perputaran Persediaan)

Dari tabel di atas diperoleh nilai thitung untuk perputaran persediaan $\left(X_{3}\right)$ sebesar 5,379 dan ttabel sebesar I,9705. Dikarenakan nilai thitung lebih besar dari nilai tabel $(5,378>1,9705)$ dengan nilai signifikansi $0, \mathrm{I} I 7>0,05$ maka $\mathrm{H} 0$ diterima, artinya modal kerja dalam perputaran persediaan $\left(\mathrm{X}_{3}\right)$ berpengaruh secara signifikan terhadap profitabilitas $(\mathrm{Y})$ pada Perusahaan Delta Djakarta Tbk.

\section{Pengujian Hipotesis Secara Simultan (Uji F)}

\begin{tabular}{|c|c|c|c|c|c|c|}
\hline \multicolumn{2}{|c|}{ ANOYAa } \\
\hline \multicolumn{2}{|c|}{ Model } & $\begin{array}{c}\text { Sum of } \\
\text { Squares }\end{array}$ & Df & $\begin{array}{c}\text { Mean } \\
\text { Square }\end{array}$ & F & Sig. \\
\hline \multirow{2}{*}{1} & Regression & .001 & 3 & .000 & 117838.237 & $.002^{\mathrm{b}}$ \\
\cline { 2 - 7 } & Residual & .000 & 1 & .000 & & \\
\cline { 2 - 7 } & Total & .001 & 4 & & & \\
\hline \multicolumn{7}{|l|}{ a. Dependent Variable: abs_res_1 } \\
\hline \multicolumn{7}{|l|}{ b. Predictors: (Constant), PERSEDIAAN, KAS, PIUTANG } \\
\hline
\end{tabular}

Hasil Uji F.

Berdasarkan tabel sumber: Output SPSS 25, data yang diolah berdasarkan output $4.1 \mathrm{I}$ di atas diketahui nilai Fhitung sebesar II7838.237 dengan nilai signifikansi (sig.) $=0,000$. Dengan $\alpha=$ $0,05, \mathrm{df} \mathrm{I}=3$, dan $\mathrm{df} 2=\mathrm{I}(\mathrm{n}-\mathrm{k}-\mathrm{I})$, maka didapat Ftabel sebesar 2,6444. Dikarenakan nilai Fhitung $>$ Ftabel ( I I $7838.237>2,6444$ ) dan nilai signifikansi 0,002 < 0,05 maka H0 ditolak, artinya perputaran kas $(X 1)$, perputaran piutang $\left(X_{2}\right)$ dan perputaran persediaan $(X 3)$ secara simultan memberikan pengaruh terhadap profitabilitas (Y) pada Perusahaan Delta Djakarta Tbk. 


\section{Analisis Koefisien Determinasi (R-Square)}

Besarnya kontribusi varibel komponen modal kerja yang terdiri atas perputaran kas, perputaran piutang, dan perputaran persediaan terhadap profitabilitas ditunjukkan dengan besarnya koefisien determinasi (adalah hasil pengkuadratan dari koefisien korelasi dikali $100 \%$ ) atau $R$ Square. Koefisien determinasi dapat dilihat pada tabel berikut :

\section{Uji Determinasi}

\begin{tabular}{|c|c|c|c|c|}
\hline \multicolumn{5}{|c|}{ Model Summary $^{\mathbf{b}}$} \\
\hline Model & $\mathrm{R}$ & $\begin{array}{c}\mathrm{R} \\
\text { Square }\end{array}$ & $\begin{array}{c}\text { Adjusted R } \\
\text { Square }\end{array}$ & $\begin{array}{c}\text { Std. Error of the } \\
\text { Estimate }\end{array}$ \\
\hline 1 & $.988^{\mathrm{a}}$ & .977 & .908 & .038533 \\
\hline a. Predictors: (Constant), PERSEDIAAN, KAS, PIUTANG \\
\hline \multicolumn{5}{|c|}{ b. Dependent Variable: ROA } \\
\hline
\end{tabular}

Berdasarkan tabel di atas, diketahui nilai $R$ square sebesar 0,977 atau 97,7\% Dengan demikian, nilai $R$ square sebesar $97,7 \%$ yang menunjukkan arti bahwa variabel perputaran kas (XI), perputaran piutang $\left(X_{2}\right)$ dan perputaran persediaan $\left(X_{3}\right)$ memberikan kontribusi terhadap variabel profitabilitas pada Prusahaan Delta Djakarta Tbk sebesar 97,7\% Sedangkan sisanya sebesar 100\% $97,7 \%=3,3 \%$ lainnya dipengaruhi oleh variabel lain yang tidak diteliti.

\section{PEMBAHASAN}

\section{Pengaruh Tingkat Perputaran Kas, Piutang, Persediaan Terhadap Profitabilitas Secara Parsial \\ Pengaruh Perputaran Kas terhadap Profitabilitas}

Dari analisis yang telah dilakukan, dapat diperoleh nilai thitung untuk perputaran kas (XI) sebesar $-4,608$ dan tabel sebesar - I,9705 (Tabel 4.8). Dikarenakan nilai thitung lebih besar dari ttabel $(-4,608>-1,9705)$ dengan nilai signifikansi $0,136>0,05$ maka $\mathrm{HO}$ ditolak dan nilai thitung berada di daerah penerimaan $\mathrm{H} 0$ atau berada di antara ttabel sehingga dapat disimpulkan bahwa hipotesis yang diajukan "Perputaran Kas tidak berpengaruh secara signifikan terhadap profitabilitas pada Perusahaan PT. DELTA Djakarta Tbk" dapat diterima.

\section{Pengaruh Perputaran Piutang terhadap Profitabilitas}

Variabel independen lainnya yaitu perputaran piutang. Dari analisis yang telah dilakukan, diperoleh nilai thitung untuk perputaran piutang $(X 2)$ sebesar $-0,488$ dan ttabel I,9705. Dikarenakan nilai thitung lebih kecil dari nilai ttabel $(-0,488<1,9705)$ dengan nilai signifikansi 0,7 II $>0,05$ maka $\mathrm{HO}$ diterima dan nilai thitung berada di daerah penerimaan $\mathrm{HO}$ atau lebih kecil dari ttabel sehingga dapat disimpulkan bahwa hipotesis yang diajukan yakni "Modal kerja dalam perputaran piutang (X2) berpengaruh secara signifikan terhadap profitabilitas pada Perusahaan PT. DELTA Djakarta Tbk" dapat diterima.

\section{Pengaruh Perputaran Persediaan terhadap Profitabilitas}

Dalam hal variabel perputaran persediaan dari penelitian yang telah dilakukan, dapat diperoleh nilai thitung untuk perputaran persediaan (X3) sebesar 5,379 dan ttabel sebesar 1,9705. Dikarenakan nilai thitung lebih besar dari nilai ttabel $(5,379>1,9705)$ dengan nilai signifikansi 0,1 I $7>0,05$ maka $\mathrm{H} 0$ ditolak dan nilai thitung berada di daerah penolakan $\mathrm{H} 0$ atau lebih besar dari tabel sehingga dapat disimpulkan bahwa hipotesis yang diajukan yakni "Modal kerja dalam perputaran persediaan berpengaruh secara signifikan terhadap profitabilitas pada Perusahaan PT. DELTA Djakarta Tbk" dapat diterima.

\section{Pengaruh Tingkat Perputaran Komponen Modal Kerja Terhadap Profitabilitas Secara Simultan}

Nilai Fhitung $>$ Ftabel $(\mathrm{I} I 7838,273>2,6444)$ dan nilai signifikansi $0,000<0,05$ maka $\mathrm{H} 0$ ditolak, artinya perputaran kas $(X 1)$, perputaran piutang $\left(X_{2}\right)$ dan perputaran persediaan $\left(X_{3}\right)$ secara 
simultan memberikan pengaruh terhadap profitabilitas (Y) pada Perusahaan PT. DELTA Djakarta Tbk.

\section{E. KESIMPULAN DAN SARAN Kesimpulan}

1. Terdapat pengaruh perputaran kas terhadap profitabilitas pada perusahaan PT. DELTA Djakarta Tbk pada priode 2014 - 2018. Turunnya perputaran kas salah satunya disebabkan oleh adanya saldo kas yang semakin besar, sehingga kurang efisien perusahaan tersebut dalam penggunaan kasnya baik dalam ketersediaan kas yang dimiliki perusahaan masih rendah untuk memenuhi tagihan atau kegiatan operasional perusahaan yang terkait dengan penjualan. Setelah dilakukan penelitian terbukti bahwa terdapat pengaruh antara perputaran kas terhadap profitabilitas perusahaan PT. Djakarta Tbk periode 20I4-20I8. Hal tersebut membuktikan semakin tinggi perputaran kas akan semakin baik, ini berarti semakin tinggi efisiensi penggunaan kasnya dan profitabilitas yang diperoleh akan semakin besar.

2. Terdapat pengaruh perputaran piutang terhadap profitabilitas pada perusahaan PT. DELTA Djakarta Tbk priode 20l4-2018. Turunnya perputaran piutang salah satunya disebabkan oleh penurunan penjulan tetapi piutang terus meningkat, dalam periode perputaran piutang masalah yang timbul dari adanya penunggakan yang dikarenakan terlambatnya membayar hingga ketidakmampuan dalam melunasi hutang kepada perusahaan akan mengakibatkan perputaran piutang yang tidak efektif, sehingga dapat menghambat kegiatan operasional perusahaan yang membutuhkan kas lancar untuk membiayai kegiatan tersebut. Setelah dilakukan penelitian terbukti bahwa terdapat pengaruh antara perputaran piutang terhadap profitabilitas pada perusahaan PT. DELTA Djakarta Tbk priode 20I4-20I8. Hal tersebut membuktikan semakin cepat periode perputaran piutang, maka semakin cepat perusahaan mendapatkan keuntungan dari penjualan kredit tersebut, sehingga profitabilitas perusahaan juga ikut meningkat.

3. Terdapat pengaruh perputaran persediaan terhadap profitabilitas pada perusahaan PT. DELTA Djakarta Tbk priode 20I4-20I8. Turunnya perputaran persediaan salah satunya disebabkan oleh tingginya persediaan yang dimiliki perusahaan yang masih tersimpan di gudang persediaan. Hal tersebut menunjukkan kinerja perusahaan belum berjalan secara efektif dan produktif atau masih banyak barang persediaan yang menumpuk hal ini akan mengakibatkan investasi dalam tingkat pengembalian rendah. Setelah dilakukan penelitian terbukti bahwa terdapat pengaruh antara perputaran persediaan terhadap profitabilitas pada perusahaan PT. DELTA Djakarta Tbk priode 20|4-20।8. Hal tersebut membuktikan bahwa semakin cepat persediaan dirubah menjadi barang dagang yang nantinya akan dijual oleh perusahaan maka akan semakin tinggi pula tingkat profitabilitas perusahaan, maka akan semakin baik bagi kelangsungan hidup perusahaan tersebut.

4. Terdapat pengaruh perputaran modal kerja yang diukur oleh perputaran kas, perputaran piutang dan perputaran persediaan terhadap profitabilitas pada perusahaan PT. DELTA Djakarta Tbk priode 2014-2018. Masih terdapat penurunan perputaran kas, perputaran piutang ataupun perputaran persediaan pada beberapa perusahaan PT. DELTA Djakarta Tbk priode 20I4-20I8. Sehingga menyebabkan turunnya jumlah penjualan yang dihasilkan, kurangnya dana untuk membiayai operasional perusahaan, dan turunnya profitabilitas perusahaan. Hal ini membuktikan bahwa apabila perputaran modal kerja diukur oleh perputaran kas, perputaran piutang dan perputaran persediaan dilakukan secara efektif, maka akan meningkatkan profitabilitas perusahaan dan jumlah penjualan terus meningkat.

\section{Saran}

1. Saran Bagi Pengembangan IImu

Kegunaan ilmu ini diharapkan dapat berguna untuk mengembangkan ilmu akuntansi dengan penelitian secara empiris mengenai perputaran modal kerja yang diukur oleh perputaran kas, perputaran piutang dan perputaran persediaan terhadap profitabilitas $(R O A)$ sangat penting untuk dipelajari dan dipahami terkait investasi total perusahaan pada aktiva lancar atau aktiva yang diharapkan dapat dikonversi menjadi kas dalam waktu satu tahun atau kurang dari satu tahun 
untuk membiayai kegiatan operasional perusahaan sehingga dapat meningkatkan profitabilitas perusahaan. Maka disarankan bagi peneliti selanjutnya agar dapat menggunakan seluruh perusahaan yang listing di Bursa Efek Indonesia atau perusahaan di sektor lainnya yang listing di Bursa Efek Indonesia. Peneliti selanjutnya juga disarankan untuk menambah variabel lain yang sekiranya mempengaruhi profitabilitas perusahaan seperti halnya struktur modal, likuiditas, corporate social responsibilty, biaya kualitas, dan lainnya. Hal ini sesuai dengan hasil koefisien determinasi yang menunjukkan bahwa $35,5 \%$ adalah faktor-faktor lain yang tidak digunakan dalam model penelitian. Selain itu agar hasil penelitian ini dapat digunakan secara luas, maka untuk peneliti selanjutnya disarankan dapat menggunakan periode penelitian dengan tahun terbaur, halhal tersebut dimaksudkan agar penelitian selanjutnya dapat memberikan gambaran lebih luas mengenai pengaruh perputaran modal kerja yang diukur oleh perputaran kas, perputaran piutang dan perputaran persediaan terhadap tingkat profitabilitas $(R O A)$ perusahaan.

\section{Saran Bagi Operasional}

Setelah mengamati dan menganalisa hasil penelitian, penulis melihat hal yang dapat dijadikan masukan bagi perusahaan yang listing di Bursa Efek Indonesia jika dilihat dari hasil penelitian yang menunjukkan bahwa adanya pengaruh perputaran modal kerja yang diukur oleh perputaran kas, perputaran piutang dan perputaran persediaan terhadap profitabilitas (ROA) perusahaan. Maka disarankan untuk perusahaan yang listing di Bursa Efek Indonesia agar dapat memperbaiki dan meningkatkan perputaran modal kerjanya yang dilihat dari perputaran kas seperti halnya meningkatkan efisiensi dan efektifitas ketersediaan kas yang dimiliki perusahaan, perputaran piutang seperti halnya meminimalisir tingginya piutang yang dimiliki perusahaan dengan meminimalisir penjualan secara kredit, dan perputaran persediaan seperti halnya meningkatkan penjualan persediaan sehingga tidak menyebabkan menumpuknya persediaan digudang yang menyebabkan biaya perawatan persediaan meningkat. Hal tersebut dimaksudkan agar tidak menghambat perusahahaan dalam membiayai kegiatan operasionalnya sehingga dapat berjalan lancar.

\section{F. DAFTAR PUSTAKA}

Kasmir 2016 Analisis Laporan Keuangan, Jakarta : Gramedia

Rudianto 2012 Analisis Laporan

Sugiyono 2016 Metode Penelitian EDISI II Yogyakarta : Gramedia

Keuangan, Yogyakarta : Gramedia

V. Wiratna Sujarweni 2016 Analisis Laporan Keuangan, Bandung : Gunung Agung 